\title{
Bacterial Artificial Chromosome-Based Lambda Red Recombination with the I-Scel Homing Endonuclease for Genetic Alteration of MERS-CoV
}

\author{
Anthony R. Fehr
}

\begin{abstract}
Over the past two decades, several coronavirus $(\mathrm{CoV})$ infectious clones have been engineered, allowing for the manipulation of their large viral genomes $(\sim 30 \mathrm{~kb})$ using unique reverse genetic systems. These reverse genetic systems include targeted recombination, in vitro ligation, vaccinia virus vectors, and bacterial artificial chromosomes (BACs). Quickly after the identification of Middle East respiratory syndrome$\mathrm{CoV}$ (MERS-CoV), both in vitro ligation and BAC-based reverse genetic technologies were engineered for MERS-CoV to study its basic biological properties, develop live-attenuated vaccines, and test antiviral drugs. Here, I will describe how lambda red recombination can be used with the MERS-CoV BAC to quickly and efficiently introduce virtually any type of genetic modification (point mutations, insertions, deletions) into the MERS-CoV genome and recover recombinant virus.
\end{abstract}

Key words Coronavirus, MERS-CoV, Bacterial artificial chromosome (BAC), Lambda red recombination, Reverse genetics, Infectious clone

\section{Introduction}

Coronaviruses are large, enveloped, single-stranded positive-sense RNA viruses that cause both significant human and veterinary disease. Prior to the severe acute respiratory syndrome-CoV (SARS-CoV) outbreak in 2003, human CoVs were only known to cause mild, self-limiting upper respiratory diseases. Approximately 10 years after the emergence of SARS-CoV in 2012, Middle East respiratory syndrome (MERS)-CoV emerged in the Middle East where it then spread to 27 different countries, and to date (December 2018, WHO) there have been 2278 laboratoryconfirmed cases and 806 associated deaths for a case fatality rate of $35 \%$. Most of these cases have occurred in the Middle East, aside from an outbreak of 200 infected individuals in South Korea in 2015 [1]. 
Infectious clones are highly valuable research tools that enable modification of viral genomes to better understand their fundamental biology, develop novel vaccine candidates, and test antiviral therapeutics. Soon after identifying MERS-CoV as the causative agent of MERS, two distinct infectious clones were reported for MERS-CoV $[2,3]$. These infectious clones were engineered using in vitro ligation or bacterial artificial chromosomes (BACs), each of which had been used previously for CoVs [4-6]. In vitro ligation uses unique type II restriction endonucleases that cleave several bases away from their recognition site, allowing for the reassembly of authentic $\mathrm{CoV}$ genomes from smaller fragments. Each fragment is separately maintained in its own small plasmid for efficient genetic modification using traditional molecular cloning methods. Separating specific nucleotide sequences in ORFlA helped to eliminate the problem of these sequences being toxic for bacteria. A T7 promoter is inserted at the $5^{\prime}$ end of the genome, allowing for in vitro transcription of the viral RNA and subsequent transfection into mammalian cells for virus production. In contrast, BACs allow for the stable propagation of full-length $\mathrm{CoV}$ cDNA in bacteria, due to the ability to restrict their copy number to 1 or 2 plasmids per cell. Different restriction fragments of these BACs can be sub-cloned into smaller vectors for efficient modification, or the full-length genome can be modified using lambda red recombination, which will be discussed here. CoV BAC plasmids contain a CMV promoter $5^{\prime}$ of the viral genome, allowing for transcription of the viral genome following transfection of BAC DNA into mammalian cells. In addition, the CoV BACs contain a polyA tail, a Hepatitis D Virus (HDV) ribozyme, and bovine growth hormone (BGH) termination and polyadenylation signals to create genomic RNA with an authentic $3^{\prime}$ end. The full-length nature of BAC DNA and the CMV promoter subvert the need for in vitro ligation or transcription to recover infectious virus. BACs were initially developed in the early 1990s, and by the mid-late 1990s they were utilized by Herpes virologists for modification of these large DNA viruses, which revolutionized the field. A few years later a BAC for a $\mathrm{CoV}$, transmissible gastroenteritis virus (TGEV), was engineered, and since then BACs have been successfully developed for several CoVs including feline infectious peritonitis virus (FIPV), OC-43, SARS-CoV, MERS-CoV, murine hepatitis virus strain JHM (MHV-JHM), porcine epidemic diarrhea virus (PEDV), and the SARS-like CoV WIV-1 [2, 4, 7-12]. Thus, it is likely that BAC-based reverse genetics could be useful for any novel or emergent $\mathrm{CoV}$.

Lambda red recombination utilizes bacteriophage enzymes Exo, Beta, and Gam (Red proteins) to mediate homologous recombination near the ends of linear double-stranded DNA $[13,14]$. PCR products containing positive selection markers are suitable substrates for these enzymes, so long as they bear 
extensions of $40-50$ bases that are homologous to the target sequence. A major advancement in this technique came with the development of an E. coli strain, DY380, where the Red proteins were placed under the control of a temperature-inducible promoter [15]. Several methods for removing the positive selection markers from the viral genomes have been developed, including flanking sequences with FRT or loxP sites [16], or utilizing positive and negative selection markers on a single gene cassette, such as the Galactose Kinase (GalK)-Kan ${ }^{\mathrm{R}}$ gene cassette [17]. These methods both have certain downfalls, including the retention of small FRT or loxP sites following removal of the marker, or the unintended removal of negative selection markers by repeat sequences in the BAC plasmid. To improve the efficiency of removing the positive selection marker, a unique method utilizing the I-SceI homing endonuclease under an arabinose-inducible promoter was developed (Fig. 1) [18]. I-SceI is an endonuclease with an 18 bp recognition site that is not present in the E. coli genome, making it safe to express in E. coli. In the method described here, this recognition site is engineered on a plasmid (pEP-KanS) just outside of the positive selection marker, and its cleavage with the I-SceI enzyme allows for the removal of the positive selection marker by intramolecular Red recombination utilizing sequence duplication introduced in the original PCR primers. This method can be utilized to introduce any type of modification into the BAC DNA, including mutations, deletions, and insertions. Here I will outline the procedure for this highly efficient method to engineer markerless modifications, focusing on single point mutations in the full-length MERS-CoV BAC.

\section{Materials}

\subsection{Manipulation of the MERS-CoV BAC}

2.1.1 Plasmids and

Bacterial Strains
1. pBAC-MERS-CoV ${ }^{\mathrm{FL}}$. This MERS-CoV BAC was first engineered by the Luis Enjuanes lab [2]. The full protocol for creating this BAC was subsequently published by the same group in a previous Methods in Molecular Biology book [19]. This plasmid contains the parA, parB, and parC genes derived from the E. coli $\mathrm{F}$-factor to prevent more than one or two BACs from coexisting in the same cell. It also contains genes involved in the initiation and orientation of DNA replication and the chloramphenicol resistance gene $\left(\mathrm{Cml}^{r}\right)$.

2. pEP-KanS. This plasmid contains the AphAI-I-SceI cassette containing a kanamycin resistance marker $\left(\mathrm{Kan}^{r}\right)$ and an I-SceI restriction site [18]. This plasmid also contains an ampicillin resistance marker.

3. E. coli strains DHl0B (see Notel) and GS1783 (see Note 2) cells. 
A.

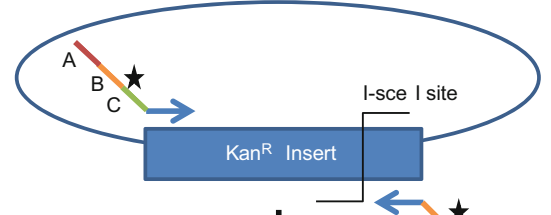

B.

Amplify using pEP-KanS

plasmid creating mutation. Dpnl digest and purify.

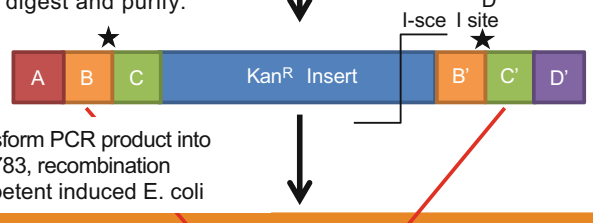

C.

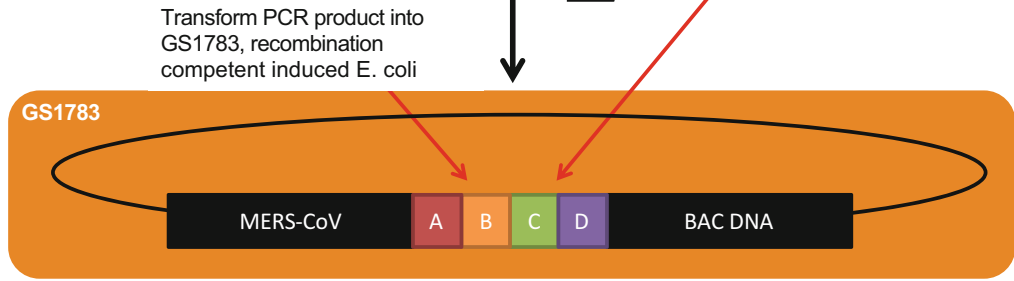

D.
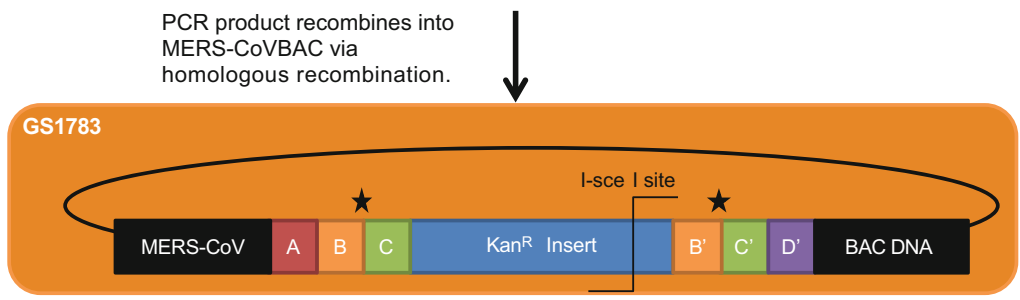

E.

Induce I-sce I restriction

enzyme with Arabinose.
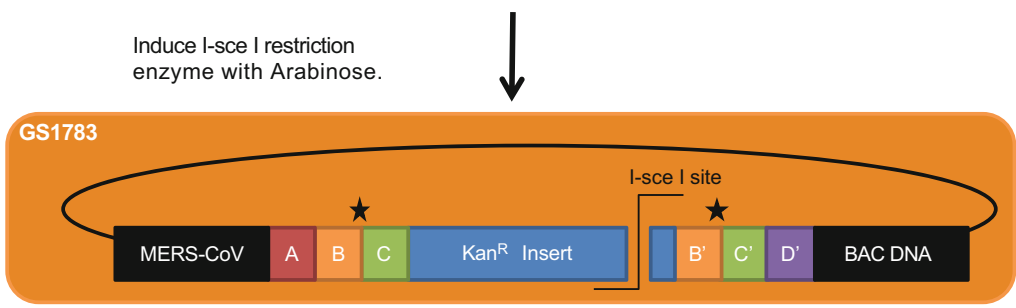

F.

Induce RED recombination enzymes with heat shock.
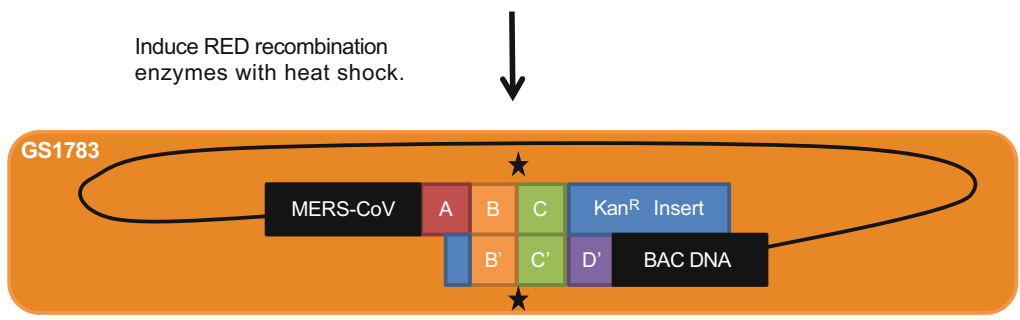

G.

$B$ and $C$ regions recombine removing $\operatorname{Kan}^{\mathrm{R}}$ and leaving the mutation
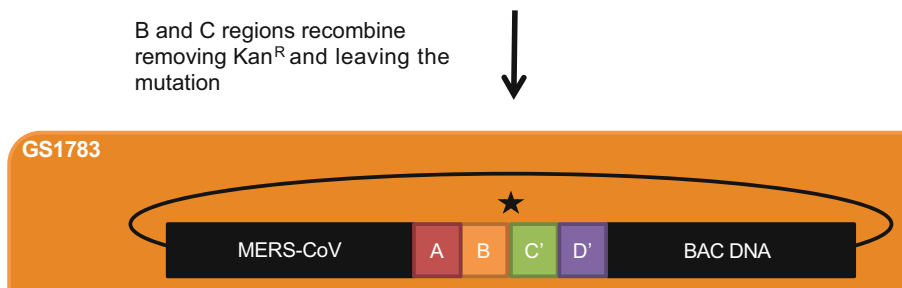

Fig. 1 Schematic for making point mutations in MERS-CoV using Lambda Red Recombination. This diagram illustrates and describes each individual step $(\mathbf{a}-\mathbf{g})$ in the protocol for creating individual point mutations in the MERS-COV BAC 
2.1.2 Culture and Freezing Reagents for E. coli

2.1.3 Enzymes

\subsubsection{DNA Oligomers}

1. LB medium: $1 \%(\mathrm{w} / \mathrm{v})$ tryptone, $0.5 \%(\mathrm{w} / \mathrm{v})$ yeast extract, $1 \%$ $(\mathrm{w} / \mathrm{v}) \mathrm{NaCl}$. Sterilize by autoclaving on liquid cycle.

2. LB agar plates: LB medium containing $15 \mathrm{~g} / \mathrm{L}$ agar. After preparing LB medium add the agar. Sterilize by autoclaving as above. Allow the medium to cool to $\sim 45-50{ }^{\circ} \mathrm{C}$, add appropriate antibiotics $(1 \mathrm{~mL}$ of $1000 \times$ stocks $/ \mathrm{L})$ or arabinose $(40 \mathrm{~mL}$ of $25 \%$ arabinose $/ \mathrm{L})$ to the medium, then dispense in Petri dishes.

3. LB freezing medium: $40 \%(\mathrm{v} / \mathrm{v})$ glycerol in LB medium. Add glycerol, water, and dry LB ingredients to desired volume (i.e., $200 \mathrm{~mL}$ of glycerol for $500 \mathrm{~mL}$ total LB freezing medium). Sterilize by autoclaving on liquid cycle.

4. LB cml media: LB medium with chloramphenicol $(25 \mathrm{mg} /$ $\mathrm{mL})$.

5. LB cml/kan media: LB media with chloramphenicol $(25 \mathrm{mg} /$ $\mathrm{mL})$ and kanamycin $(40 \mathrm{mg} / \mathrm{mL})$.

6. SOC medium: $2 \%(\mathrm{w} / \mathrm{v})$ tryptone, $0.5 \%(\mathrm{w} / \mathrm{v})$ yeast extract, $0.05 \%(\mathrm{w} / \mathrm{v}) \mathrm{NaCl}, 2.5 \mathrm{mM} \mathrm{KCl}, 10 \mathrm{mM} \mathrm{MgCl} 2,10 \mathrm{mM}$ $\mathrm{MgSO} 4,20 \mathrm{mM}$ glucose. Sterilize by autoclaving on liquid cycle.

7. Antibiotics: Make $1000 \times$ stock solutions of ampicillin (100 mg/mL in ethanol), kanamycin $\left(40 \mathrm{mg} / \mathrm{mL}\right.$ in $\left.\mathrm{H}_{2} \mathrm{O}\right)$, and chloramphenicol $(25 \mathrm{mg} / \mathrm{mL}$ in ethanol).

8. Arabinose: Make 25\% (w/v) solution in $\mathrm{H}_{2} \mathrm{O}$. Sterilize by passing it through a $0.22 \mu \mathrm{m}$ disposable filter.

9. Glycerol: Make a $10 \%(\mathrm{v} / \mathrm{v})$ solution and sterilize by autoclaving on liquid cycle.

1. Restriction endonucleases, Taq DNA polymerase, high-fidelity thermostable DNA polymerase, and reverse transcriptase can be purchased from several different commercial sources.

1. DNA oligomers can be purchased from several different commercial sources. Long DNA oligos $(>80 \mathrm{nt})$ are needed, so identifying a commercial source that can make long oligos at a reasonable price is important (see Note 3 ).

2. Recombination Primers.

Forward: $5^{\prime}$ 60bp_homology -AGGATGACGACGATAAGTAGGG-3'.

Reverse: 5'------60bp_homology-----GCCAGTGTTACA ACCAATTAACC- $3^{\prime}$. 
2.1.5 DNA Preparation Kits

2.1.6 Special Software and Equipment

2.2 Rescue of BACDerived Recombinant Viruses
1. DNA Miniprep Kit.

2. Machery-Nagel Nucleobond Xtra Midi Kit (see Note 4).

3. Invitrogen PureLink PCR Purification Kit (see Note 5).

1. Electroporator and $1 \mathrm{~mm}$ cuvettes.

2. $42{ }^{\circ} \mathrm{C}$ shaking water bath ( see Note 6).

3. $30-32{ }^{\circ} \mathrm{C}$ incubator and shaking incubator.

4. DNA analysis software.

1. Human liver-derived Huh-7 (JCRB Cell Bank, JCRB0403) or Vero cells (ATCC, CCL-81).

2. Cell growth medium: Dulbecco's Modified Eagle Medium $($ DMEM $)+10 \%$ FBS .

3. Cell growth medium: DMEM $+2 \%$ FBS.

4. Opti-MEM I Reduced Serum Medium.

5. Trypsin-EDTA: $0.05 \%(\mathrm{w} / \mathrm{v})$ trypsin, $0.02 \%(\mathrm{w} / \mathrm{v})$ EDTA.

6. Lipofectamine 2000 (Life Technologies, Invitrogen) (see Note 7).

\section{Methods}

\subsection{Transformation and Storage of MERS- CoV BAC DNA into DH1OB or GS1783 Cells}

1. Precool electroporation cuvette at $4{ }^{\circ} \mathrm{C}$ or on ice.

2. Prepare labeled $14 \mathrm{~mL}$ culture tube(s) with $1 \mathrm{~mL}$ SOC.

3. Add 1-10 ng of BAC DNA in a sterile Eppendorf tube on ice. Add $24 \mu \mathrm{L}$ of electrocompetent DH10B or GS1783 E. coli.

4. Carefully transfer the mixture into the groove of an electroporation cuvette on ice.

5. Pulse the cuvette at $25 \mu \mathrm{F}, 1750 \mathrm{~V}$, and $200 \Omega$.

6 . Recover by adding $0.5-1.0 \mathrm{~mL}$ SOC to the cuvette, and transfer the mixture to a $14 \mathrm{~mL}$ culture tube. Incubate at $32{ }^{\circ} \mathrm{C}$ and $220 \mathrm{rpm}$ for $1 \mathrm{~h}$. Pre-warm LB-agar-cml plate.

7. Add $25-50 \mu \mathrm{L}$ of culture to $\mathrm{LB}-\mathrm{cml}$ plate. Incubate at 30-32 ${ }^{\circ} \mathrm{C}$ overnight $(\mathrm{o} / \mathrm{n})$ ( see Note 8$)$.

8. Next day pick $1-2$ colonies and incubate in $2 \mathrm{~mL} \mathrm{LB}-\mathrm{cml}$ broth at $30-32{ }^{\circ} \mathrm{C} \mathrm{o} / \mathrm{n}$.

9. Next day mix $0.5 \mathrm{~mL} \mathrm{o} / \mathrm{n}$ culture with $0.5 \mathrm{~mL}$ bacterial freezing medium. Store in negative $80^{\circ} \mathrm{C}$ freezer.

Day 1

3.2 Prepare pBACMERS-CoV Competent Cells for Lambda Red Recombination
1. Streak glycerol stock of GS1783 pBAC-MERS-CoV bacteria generated in 3.1 on $\mathrm{LB}-\mathrm{cml}$ plate to generate isolated colonies. Incubate at $30-32{ }^{\circ} \mathrm{C} \mathrm{o} / \mathrm{n}$. 
Day 2

2. Pick one colony from the plate and transfer to $2 \mathrm{~mL} \mathrm{LB}-\mathrm{cml}$ in tube. Incubate at $30-32{ }^{\circ} \mathrm{C}$ and $220 \mathrm{rpm} \mathrm{o} / \mathrm{n}$. Put $\mathrm{ddH}_{2} \mathrm{O}$ $(200 \mathrm{~mL})$ and $10 \%$ glycerol in $\mathrm{ddH}_{2} \mathrm{O}(100 \mathrm{~mL})$ at $4{ }^{\circ} \mathrm{C}$ to precool.

Day 3

3. Dilute $1 \mathrm{~mL}$ of $\mathrm{o} / \mathrm{n}$ culture into $49 \mathrm{~mL} \mathrm{LB}-\mathrm{cml}$ in a $250 \mathrm{~mL}$ Erlenmeyer flask. Protocol can be scaled up to $100 \mathrm{~mL}$ (use $500 \mathrm{~mL}$ Erlenmeyer flask). Incubate at $32{ }^{\circ} \mathrm{C}$ and $220 \mathrm{rpm}$. In the meantime, turn on shaking water bath, check water level, and set to $42{ }^{\circ} \mathrm{C}$. Label 10 Eppendorf tubes per $50 \mathrm{~mL}$ culture and precool them in a plastic tube rack at $-80{ }^{\circ} \mathrm{C}$. Precool the tabletop centrifuge with the swinging bucket rotor and a microcentrifuge to $4{ }^{\circ} \mathrm{C}$.

4. Monitor the $\mathrm{OD}_{600}$ of culture starting at $2 \mathrm{~h}$ of incubation. When $\mathrm{OD}_{600}=0.6-0.8(\sim 3-4 \mathrm{~h})$, incubate at $42{ }^{\circ} \mathrm{C}$ and $200 \mathrm{rpm}$ ( see Note 9) in shaking water bath for $15 \mathrm{~min}$. In the meantime, prepare an ice water slurry in an autoclave bin or other suitable container and get a bucket of ice. Place two $50 \mathrm{~mL}$ conical tubes on ice.

5. Swirl the Erlenmeyer flask in the ice water slurry for $10 \mathrm{~min}$. From here on, keep bacteria cold at all times.

6. Aliquot $25 \mathrm{~mL}$ into each $50 \mathrm{~mL}$ conical tube on ice. Centrifuge at $1800 \times g$ for $10 \mathrm{~min}$ at $4{ }^{\circ} \mathrm{C}$ in a tabletop centrifuge.

7. Pour off supernatant with one quick motion. While pouring, position the bacterial pellet away from the liquid to limit the amount of bacteria lost. Add $5 \mathrm{~mL}$ ice-cold sterile $\mathrm{ddH}_{2} \mathrm{O}$ and resuspend pellet by swirling and tapping the tube to the bottom of the ice-cold autoclave bin. Once resuspended, add an additional $20 \mathrm{~mL}$ ice-cold sterile $\mathrm{ddH}_{2} \mathrm{O}$ and centrifuge at $1800 \times g$ for $10 \mathrm{~min}$ at $4^{\circ} \mathrm{C}$. Repeat $1 \times$.

8. Following the second water wash, resuspend each pellet with $10 \%$ glycerol, first in $5 \mathrm{~mL}$, then add an additional $15 \mathrm{~mL}$. Centrifuge at $1800 \times \mathrm{g}$ for $10 \mathrm{~min}$ at $4{ }^{\circ} \mathrm{C}$.

9. Pour off supernatant as described above. Following the pour, resuspend the pellet in the remaining $10 \%$ glycerol $(\sim 500 \mu \mathrm{L})$. If the combined amount of cells and $10 \%$ glycerol is greater than $550 \mu \mathrm{L}$, transfer the suspension to a cold Eppendorf tube and pellet the cells for $2 \mathrm{~min}$ at $5000 \times \mathrm{g}$ and $4{ }^{\circ} \mathrm{C}$. After spinning the cells, remove an appropriate amount of supernatant such that $\sim 500 \mu \mathrm{L}$ of cell suspension remains. Resuspend the cells to a homogenous solution and aliquot $50 \mu \mathrm{L}$ to prefrozen Eppendorf tubes and flash-freeze tubes in liquid nitrogen or a dry ice-methanol bath. Use immediately or store at $-80{ }^{\circ} \mathrm{C}$. Cells are typically good for 6-12 months, but may be useful even after several years. 


\subsection{Create PCR Cassette Containing the Viral Genome Mutation or Insertion of Interest with the AphAl-I-Scel (Herein Termed Kan'-I-Scel) Gene Cassette}

1. Design and order $\mathrm{Kan}^{r}$-I-SceI primers with $60 \mathrm{bp}$ homology to the region of interest flanking the desired site to be modified (Fig. la). To design simple point mutations, start by developing a 60 bp flanking sequence, calling each 20 base pair section as $\mathrm{A}, \mathrm{B}$, and $\mathrm{C}$. Then incorporate the desired mutation at the end of section B (40th base pair, or the 39th and 40th base pair if two changes are required). Finally, attach this sequence to the 22 bp $\mathrm{Kan}^{r}$-I-SceI sequence below to create your forward recombination primer. To create the reverse recombination primer, create a new block of 20 bp we will call section $\mathrm{D}^{\prime}$ that is the reverse complement of the sequence immediately downstream from section $\mathrm{C}$. These $20 \mathrm{bp}$ will be followed on your primer by sections $\mathrm{C}^{\prime}$ and $\mathrm{B}^{\prime}$, the reverse complements to sections $\mathrm{B}$ and $\mathrm{C}$, with $\mathrm{B}^{\prime}$ containing the desired mutations. Finally, add the 23 bp $\mathrm{Kan}^{r}$-I-SceI sequence to finish the reverse primer. During negative selection, sections $\mathrm{B} / \mathrm{C}$ will recombine with $\mathrm{B}^{\prime} / \mathrm{C}^{\prime}$ leading to the loss of the $\mathrm{Kan}^{R}$-I-SceI cassette (Fig. $1 \mathrm{~g}$ ). For deletion mutants, leave out the desired sequence from your primers. For instance, to delete sections $\mathrm{D} / \mathrm{E} / \mathrm{F}$, simply create the forward primer with sections $\mathrm{A} / \mathrm{B} /$ $\mathrm{C}$, and the reverse primer with sections $\mathrm{G}^{\prime} / \mathrm{C}^{\prime} / \mathrm{B}^{\prime}$. Insertions of small sequences can be achieved by adding the entire insertion sequence at the $3^{\prime}$ end of the forward primer, and at least 50 bp of reverse complement sequence at the $3^{\prime}$ end of the reverse primer (Fig. 2). Larger insertions may require the development of a full plasmid, or potentially the use of nested PCRs. For additional details, see ref. [18]. While designing recombination primers (indicated below), remember to also order short primers about 100-200 bp outside of the insertion site to check for the proper insertion of the gene cassette by PCR.

2. Set up PCR reaction and perform reaction according to manufacturer's protocol with following modifications (Fig. lb).

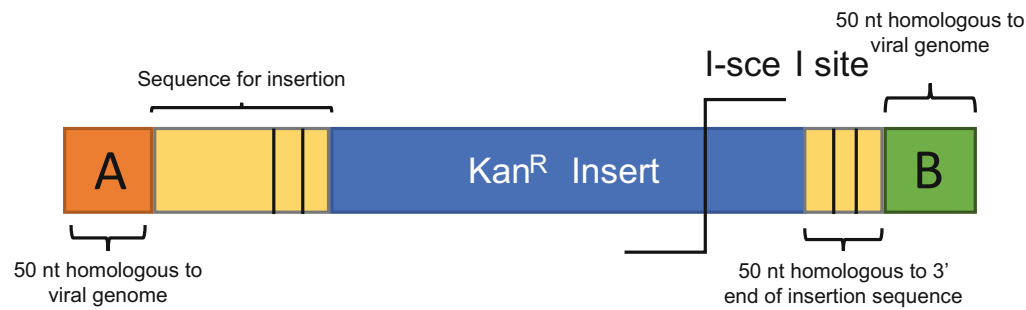

Fig. 2 Model of the PCR product used for inserting specific sequences into BACs using lambda red recombination. The full sequence for insertion is incorporated at the $5^{\prime}$ end of the $K{ }^{R}{ }^{R}-$-Scel cassette while at least 50 nt of sequence homologous to the $3^{\prime}$ end of the insertion sequence is incorporated at the $3^{\prime}$ end of this cassette. Surrounding these sequences are $50 \mathrm{nt}$ of sequence homologous to the viral sequence where the sequence is to be inserted 
3. For a PCR template, use $\sim 50$ ng of the pEP-KanS plasmid.

4. Use $1 \mu \mathrm{L}$ high-fidelity polymerase (see Note 10 ).

5. For the annealing temperature, I prefer to use a step-down procedure lowering the annealing temperature by $1{ }^{\circ} \mathrm{C}$ starting at $68^{\circ} \mathrm{C}$ and continuing the PCR reaction for 25 cycles. Using this method we rarely see spurious PCR products.

6. Analyze the PCR product on an agarose gel with ethidium bromide and image it using a UV-gel box and gel-imaging software. PCR product should be $\sim 1.2 \mathrm{~kb}$.

7. Purify the PCR product using the PureLink PCR purification kit (see Note 5). Use binding buffer B3 according to manufacturer's protocol to remove primer dimers from the mixture. Elute DNA into $44 \mu \mathrm{L}$ of water.

8. DpnI digest the pEP-KanS plasmid in the purified PCR product (Fig. 1b). DpnI specifically cleaves methylated DNA and is needed to digest the pEP-KanS plasmid used in the PCR reaction. It has a $4 \mathrm{bp}$ recognition site so it should cleave DNA approximately every $250 \mathrm{bp}$. Without this digestion all of your transformants will maintain the pEP-KanS plasmid as its transformation is much more efficient than the recombination of the PCR product. Incubate for $1-3$ h at $37^{\circ} \mathrm{C}$.

$1 \mu \mathrm{L}$ DpnI.

$5 \mu \mathrm{L}$ Buffer.

$44 \mu L$ PCR product.

$50 \mu \mathrm{L}$ Total

9. Purify PCR product using the PureLink PCR purification kit. Elute DNA into $30 \mu \mathrm{L}$ pre-warmed elution buffer or water.

10. Measure DNA concentration using a spectrophotometer. A concentration of $20-80 \mathrm{ng} / \mu \mathrm{L}$ is typical.

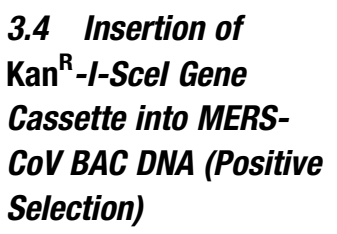

3.4 Insertion of Kan $^{\mathrm{R}}$-I-Scel Gene Cassette into MERSCoV BAC DNA (Positive Selection)
Day 1

1. Precool the electroporation cuvette(s) on ice.

2. Prepare labeled $14 \mathrm{~mL}$ culture tube(s).

3. Aliquot 50-100 ng of $\mathrm{Kan}^{r}$-I-SceI PCR product in a sterile Eppendorf tube on ice. This will generally be $2-4 \mu \mathrm{L}$. Add $23 \mu \mathrm{L}$ competent GS1783 E. coli containing pBAC-MERS$\mathrm{CoV}$ and mix by stirring briefly.

4. Carefully transfer the mixture into the groove of the electroporation cuvette on ice.

5. Wipe any ice water from outside of cuvette and pulse at $25 \mu \mathrm{F}$, $1750 \mathrm{~V}$, and $200 \Omega$ (Fig. lc). 
6. Recover by immediately adding $0.5-1 \mathrm{~mL}$ SOC to the cuvette, and then transfer the mixture to a $14 \mathrm{~mL}$ culture tube. Incubate at $32{ }^{\circ} \mathrm{C}$ and $220 \mathrm{rpm}$ for $3-5 \mathrm{~h}$. This is when the recombination occurs (Fig. 1d) ( see Note 11). Pre-warm an LB-cml/kan plate.

7. After the recovery, transfer the bacteria to a $1.5 \mathrm{~mL}$ tube and centrifuge at $16,000 \times \mathrm{g}$ for $1 \mathrm{~min}$. Remove all but $\sim 100 \mu \mathrm{L}$ of supernatant, resuspend the pellet, and plate the entire culture on an $\mathrm{LB}-\mathrm{cml} / \mathrm{kan}$ plate and incubate at $30-32{ }^{\circ} \mathrm{C} \mathrm{o} / \mathrm{n}$. You should get anywhere from 5 to 100 colonies.

Day 2

1. Using a sterile toothpick or pipet tip, replica-plate 25 colonies from the previous step first onto an LB-amp plate (ampR $=$ pEP-kanS plasmid background; all colonies should be negative if DpnI digest was complete), then onto an $\mathrm{LB}-\mathrm{cml} / \mathrm{kan}$ plate (should be positive if recombination occurred). A grid for this procedure is shown in Fig. 3. Incubate plates at $30-32{ }^{\circ} \mathrm{Co} / \mathrm{n}$.

Day 3

2. Identify bacterial clones that grew on the $\mathrm{LB}-\mathrm{cml} / \mathrm{kan}$ plate but not on the LB-amp plate. The efficiency at this step is anywhere from 50 to $100 \%$. Inoculate culture tubes containing $6 \mathrm{~mL}$ of LB-cml-kan with 5-6 selected colonies ( 1 in each tube) from the $\mathrm{LB}-\mathrm{cml} / \mathrm{kan}$ plate and incubate at $30-32{ }^{\circ} \mathrm{C}$ and $220 \mathrm{rpm} \mathrm{o} / \mathrm{n}$.
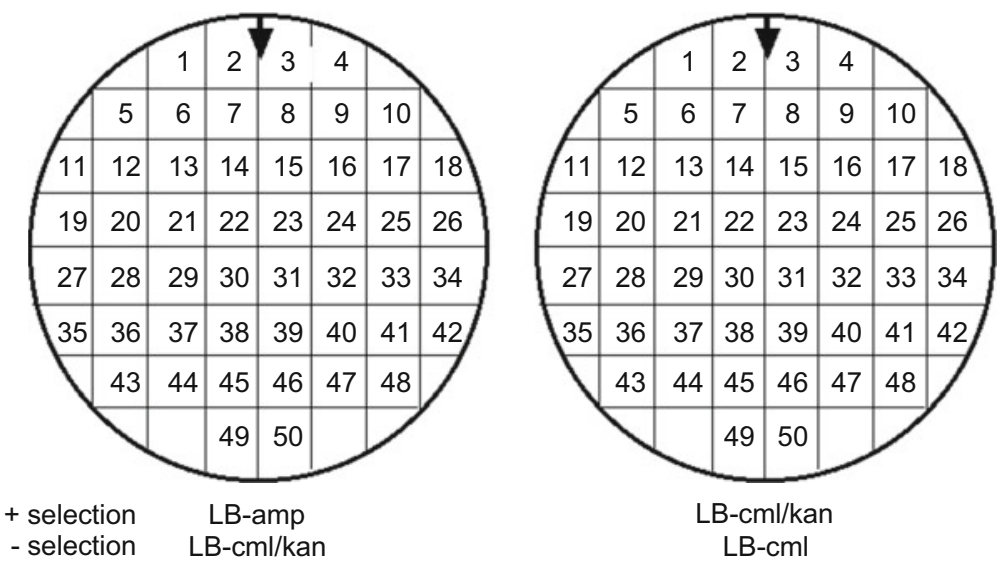

Fig. 3 Replica plate grids. These grids allow for the easy identification of identical colonies that have been plated on each plate. Using a toothpick, dot a single colony in the same spot on each plate. For both positive and negative selection, MERS-BAC clones that have successfully undergone recombination will grow on the plate on the right, but not on the plate on the left 
Day 4

3. Following $\mathrm{o} / \mathrm{n}$ incubation, create a freezer stock of the bacteria, then purify the BAC DNA using a standard miniprep kit. Using $1 \mu \mathrm{L}$ of the BAC DNA, use the external primers located 100-200 bp outside the region of homology you previously designed to test for the insertion of $\mathrm{Kan}^{r}$-I-SceI by PCR. If the insertion was successful, the DNA band from the PCR should be $\sim 1 \mathrm{~kb}$ larger than the band from the MERS-CoV wild-type BAC ( see Note 12). To speed this process up, colonies may be collected off the plate on day 3 and directly tested by PCR. Colonies that pass the PCR screen can then progress to the negative selection protocol (3.5) ( see Note 13).

3.5 Removal of $\mathrm{Kan}^{\mathrm{R}}$-I-Scel from MERS-COV BAC DNA (Negative Selection)
Day 1 (can coincide with day 4 of positive selection protocol)

1. Create two new culture tubes with $2 \mathrm{~mL}$ of $\mathrm{LB}-\mathrm{cml} / \mathrm{kan}$ and inoculate them with bacteria from 2 separate $k a n^{r}+c m l^{r}+a m p^{r}-$ colonies. Incubate at $30-32{ }^{\circ} \mathrm{C}$ and $220 \mathrm{rpm} \mathrm{o} / \mathrm{n}$.

Day 2

2. Transfer $100 \mu \mathrm{L}$ of the fresh $\mathrm{o} / \mathrm{n}$ culture to $2 \mathrm{~mL}$ of warm $\mathrm{LB}-\mathrm{cml}$ and incubate at $32{ }^{\circ} \mathrm{C}$ and $220 \mathrm{rpm}$ for $2 \mathrm{~h}$. If not previously done, mix $0.5 \mathrm{~mL} \mathrm{o} / \mathrm{n}$ culture with $0.5 \mathrm{~mL}$ freezing medium as a glycerol stock.

3. After $2 \mathrm{~h}$, add $2 \mathrm{~mL}$ of warm LB-cml with $2 \%$ arabinose to the culture tube for a final arabinose concentration of 1\% (Fig. 1). Incubate at $32{ }^{\circ} \mathrm{C}$ and $220 \mathrm{rpm}$ for $2 \mathrm{~h}$. Warm water bath shaker to $42^{\circ} \mathrm{C}$.

4. Transfer the culture tubes to the water bath shaker at $42{ }^{\circ} \mathrm{C}$ and $\sim 200 \mathrm{rpm}$ and incubate for $30 \mathrm{~min}$ (Fig. If).

5. Transfer the culture tubes back to $32{ }^{\circ} \mathrm{C}$ and incubate for $3-4 \mathrm{~h}$ (Fig. lg).

6. After the incubation, perform tenfold serial dilutions of the bacteria in LB. Plate $100 \mu \mathrm{L}$ of $10^{-4}$ and $10^{-5}$ dilutions of original culture on pre-warmed $\mathrm{LB}-\mathrm{cml}$ plates containing $1 \%$ arabinose. Incubate the plates at $30-32{ }^{\circ} \mathrm{C}$.

Day 3

7. Pick 50 colonies and replica plate on $\mathrm{LB}-\mathrm{cml} / \mathrm{kan}$ and $\mathrm{LB}-\mathrm{cml}$ plates. Colonies that underwent correct recombination should grow on LB-cml but not on LB-cml/kan. Incubate $\mathrm{o} / \mathrm{n}$ at $32{ }^{\circ} \mathrm{C}$. Efficiency is generally anywhere from 5 to $50 \%$ (see Note 14). 
Day 4

8. Pick 3 separate $\mathrm{cml}^{+} \mathrm{kan}^{-}$colonies and culture each one in $100 \mathrm{~mL} \mathrm{LB}-\mathrm{cml}$ at $32{ }^{\circ} \mathrm{C}$ and $220 \mathrm{rpm} \mathrm{o} / \mathrm{n}$.

Day 5

9. Mix $0.5 \mathrm{~mL}$ of the $\mathrm{o} / \mathrm{n}$ culture with $0.5 \mathrm{~mL}$ freezing solution for a glycerol stock. Purify the BAC DNA from these cultures using the NucleoBond Xtra Midi Kit according the manufacturer's protocol (see Note 4). Verify the integrity of the BAC constructs by restriction enzyme digestion of $\sim 2 \mu \mathrm{g}$ BAC DNA with KpnI and verify the loss of the $\mathrm{Kan}^{R}$-I-SceI gene cassette by PCR (see Note 15). Verify introduced mutation(s)/insertion(s) by Sanger sequencing.

\subsection{Rescue of Recombinant Virus}

Day 1

1. Seed either Vero-81 or Huh-7 cells (see Note 16) in DMEM + 10\% FBS into 6 well dish so that cells are $60-80 \%$ confluent at the time of transfection the next day. Incubate at $37^{\circ} \mathrm{Co}$ or.

Day 2 (BSL-3)

2. All procedures from here involve working with MERS-CoV which requires a BSL-3 containment laboratory.

3. Replace medium from cells with $2 \mathrm{~mL}$ DMEM $+10 \%$ FBS immediately before proceeding to step4.

4. Prepare the transfection mixture as follows: For a single well, mix 1-2 $\mu \mathrm{g}$ of MERS-CoV BAC DNA with $10 \mu \mathrm{L}$ Lipofectamine 2000 ( see Note 7) in Opti-MEM media according to manufacturer's protocol. Scale up accordingly if multiple BAC DNAs will be transfected. Additionally, prepare the following controls:

(a) Lipofectamine + random plasmid DNA.

(b) Lipofectamine only.

(c) No Lipofectamine, no DNA.

Wait $\sim 20 \mathrm{~min}$ for liposomes to form. Then add the transfection mixture dropwise to the medium in the well.

5. Approximately 3-4 h after transfection (see Note 17), replace the medium with a $2 \%$ (Vero 81 cells) or $10 \%$ (Huh-7 cells) FBS medium to slow cell growth.

Day 6 and Beyond (BSL-3)

6. Cytopathic effect (CPE) will start being visible at 3-4 days after transfection. Collect cells and supernatant when $>50 \%$ of well has CPE (the more the better). To collect, scrape any 
remaining cells off the well with a pipette tip or cell scraper and transfer the media and cell debris in a $2 \mathrm{~mL}$ microcentrifuge tube and freeze-thaw the sample. Then, centrifuge the sample at $\sim 5000 \times \mathrm{g}$ to spin out the cell debris and transfer the supernatant to a new tube. We term this passage 0 (P0) virus.

7. Use $\sim 1-2 \mathrm{~mL}$ of P0 virus to infect $1 \mathrm{~T}-75$ flask of cells (see Note 18 ).

8. Collect virus at $2-3$ days post-infection as describe above and aliquot. We term this as $\mathrm{Pl}$ virus. Titer virus on Vero/Huh-7 cells. If titer is sufficient, use for further experiments.

9. To verify whether the virus has maintained your mutation or insertion, infect a new set of cells for $\sim 48 \mathrm{~h}$, then collect the infected cells in Trizol, prepare RNA and then convert the RNA to cDNA with reverse transcriptase. Alternatively, you could prepare RNA from the supernatants and sequence these samples. Create a PCR product with the external primers that were previously used to check for the gain or loss of the insertion, and finally have that PCR product sequenced by Sanger sequencing ( see Note 19).

\section{Notes}

1. DH10B cells are a standard E. coli strain used for general cloning. DHl0B cells are recombination-deficient (recAl) and endonuclease I-deficient (endAl) and have constitutive deoxyribose synthesis for improved cloning of large plasmids. These traits make these cells ideal for the long-term storage of BAC plasmids.

2. GS1783 cells are a derivative of $\mathrm{DH} 10 \mathrm{~B}$ cells that contain the Red recombination genes under a temperature sensitive promoter and the I-SceI homing endonuclease under control of an arabinose-inducible promoter [20].

3 . For creating long oligos, we prefer Invitrogen as a supplier, as they can provide oligos up to $100 \mathrm{nt}$ at their standard price per base. Many companies do not make oligos longer than $60 \mathrm{nt}$ at their standard rates, and thus will charge a significant amount more for the 80-90 nt oligos required for this protocol.

4. While many companies sell BAC-prep kits which will work for these purposes, these columns are often at least $3 \times$ the cost of the Nucleobond Xtra Midi Kit. We have tested the Xtra Midi Kit side by side with a BAC-prep kit and found little to no difference in CoV BAC DNA yield.

5. For purifying PCR products, we prefer the Invitrogen PureLink PCR Purification Kit because it includes a buffer that allows DNA products of $<300$ bp to go through the column. 
This helps remove primer dimers from the PCR reaction that could interfere with recombination.

6. A $42{ }^{\circ} \mathrm{C}$ shaking water bath is essential for this procedure. The bacterial cultures need to heat up to $42{ }^{\circ} \mathrm{C}$ quickly to properly induce the Red enzymes. A shaking water bath is significantly better than a regular shaking incubator at quickly transferring heat to the bacterial culture.

7. We have tried several different transfection reagents, and Lipofectamine 2000 has worked the best for us. That does not mean other transfection reagents won't work, feel free to try whichever reagent you prefer.

8. It is important to always culture GS1783 cells at $32{ }^{\circ} \mathrm{C}$ or lower due to the potential for leaky expression of the Red enzymes at temperatures below the induction temperature of $42{ }^{\circ} \mathrm{C}$.

9. Some shaking water baths cannot shake at $200 \mathrm{rpm}$; if this is the case, simply shake at a reasonable speed for the shaker.

10. We have occasionally had problems obtaining a PCR product when using the manufacturer recommended $0.5 \mu \mathrm{L}$ of highfidelity polymerase. Using $1 \mu \mathrm{L}$ of polymerase provides more consistent results.

11. Unlike a typical $\mathrm{l}$ h recovery following electroporation, it is important to incubate these cultures for several hours in SOC to allow time for recombination to occur. A recovery time of $5 \mathrm{~h}$ or greater is preferred, with a minimal recovery time being $3 \mathrm{~h}$.

12. Occasionally, we find that following PCR some clones have bands that correspond to both the WT BAC and the desired $\mathrm{Kan}^{\mathrm{R}}$-I-SceI insert BAC. It is likely due to at least two copies of BAC DNA being present in the same cell. Unless the molar ratio of the $\operatorname{Kan}^{R}$-I-SceI insert to the WT BAC is very large, these clones should be avoided.

13. After positive selection, we do not check the BAC by restriction digest, because (a) we find that in many cases the amount of BAC DNA from a miniprep is insufficient for a readable digest, and (b) we find that the colonies that pass the replica plating and PCR tests rarely if ever have any significant problems concerning removing or duplicating regions of the MERSCoV BAC DNA.

14. First, colonies may take over 1 day before they are visible. Second, while the efficiency of the negative selection can be very low, any colonies that have grown on $\mathrm{LB}-\mathrm{cml}$ plates but do not grow on $\mathrm{LB}-\mathrm{cml} / \mathrm{kan}$ plates are very likely correct. Therefore, we go directly to starting large-scale cultures for these clones. That way we can do the final diagnostic tests and we can prepare for the BAC transfection and viral recovery at the same time. 
15. A KpnI digest of pBAC-MERS-CoV results in DNA fragments of $19.1,13.8,3.9$, and $1.5 \mathrm{~kb}$. We have found this is the best digest for diagnostic evaluation of the MERS-CoV BAC; however other enzymes or enzyme combinations will work as well. Be sure to use a low-percentage agarose gel to effectively separate the large DNA molecules.

16. Other laboratories use BHK-21 cells for the initial transfection since these cells are highly transfectable. The transfected cells can be overlaid on the Vero-81 or Huh-7 cells for further outgrowth of the recombinant virus.

17. It is feasible to wait $\mathrm{o} / \mathrm{n}$ to change the media of the transfected Vero 81 cells, but this does result in an increase in the cytotoxicity induced by Lipofectamine. This is not feasible if you are using Huh-7 cells.

18. Mutant viruses that do not replicate as well as WT virus may require increased amounts of $\mathrm{P} 0$ virus.

19. It is also beneficial to check the integrity of the entire MERS$\mathrm{CoV}$ genome by RT-PCR after several passages as MERS-CoV tends to occasionally delete sections of the accessory proteins.

\section{Acknowledgments}

I thank Jeremiah Athmer and Andrea Pruijssers for their substantial modifications and improvements to this protocol over the years. I also thank Catherine Kerr, Ethan Doerger, Andrea Pruijssers, Isabel Sola, and Luis Enjuanes for critical reading of this manuscript. This work was supported in part by NIH grants CoBRE P20 GM113117-02 and K22 AI134993-01, and start-up funds from the University of Kansas. The funders had no role in study design, data collection and interpretation, or the decision to submit the work for publication.

\section{References}

1. Fehr AR, Channappanavar R, Perlman S (2017) Middle East respiratory syndrome: emergence of a pathogenic human coronavirus. Annu Rev Med 68:387-399. https://doi.org/ 10.1146/annurev-med-051215-031152

2. Almazan F, DeDiego ML, Sola I, Zuniga S, Nieto-Torres JL, Marquez-Jurado S, Andres G, Enjuanes L (2013) Engineering a replication-competent, propagation-defective Middle East respiratory syndrome coronavirus as a vaccine candidate. MBio 4(5): e00650-e00613. https://doi.org/10.1128/ mBio.00650-13
3. Scobey T, Yount BL, Sims AC, Donaldson EF, Agnihothram SS, Menachery VD, Graham RL, Swanstrom J, Bove PF, Kim JD, Grego S, Randell SH, Baric RS (2013) Reverse genetics with a full-length infectious cDNA of the Middle East respiratory syndrome coronavirus. Proc Natl Acad Sci U S A 110(40):16157-16162. https://doi.org/10.1073/pnas.1311542110

4. Almazan F, Gonzalez JM, Penzes Z, Izeta A, Calvo E, Plana-Duran J, Enjuanes L (2000) Engineering the largest RNA virus genome as an infectious bacterial artificial chromosome. Proc Natl Acad Sci U S A 97(10):5516-5521 
5. Yount B, Denison MR, Weiss SR, Baric RS (2002) Systematic assembly of a full-length infectious cDNA of mouse hepatitis virus strain A59. J Virol 76(21):11065-11078

6. Yount B, Curtis KM, Baric RS (2000) Strategy for systematic assembly of large RNA and DNA genomes: transmissible gastroenteritis virus model. J Virol 74(22):10600-10611

7. Almazan F, Dediego ML, Galan C, Escors D, Alvarez E, Ortego J, Sola I, Zuniga S, Alonso S, Moreno JL, Nogales A, Capiscol C, Enjuanes L (2006) Construction of a severe acute respiratory syndrome coronavirus infectious cDNA clone and a replicon to study coronavirus RNA synthesis. J Virol 80 (21):10900-10906. https://doi.org/10. 1128/JVI.00385-06

8. Balint A, Farsang A, Zadori Z, Hornyak A, Dencso L, Almazan F, Enjuanes L, Belak S (2012) Molecular characterization of feline infectious peritonitis virus strain DF-2 and studies of the role of ORF3abc in viral cell tropism. J Virol 86(11):6258-6267. https:// doi.org/10.1128/JVI.00189-12

9. Fehr AR, Athmer J, Channappanavar R, Phillips JM, Meyerholz DK, Perlman S (2015) The nsp3 macrodomain promotes virulence in mice with coronavirus-induced encephalitis. J Virol 89(3):1523-1536. https://doi.org/10.1128/ JVI.02596-14

10. St-Jean JR, Desforges M, Almazan F, Jacomy H, Enjuanes L, Talbot PJ (2006) Recovery of a neurovirulent human coronavirus OC43 from an infectious cDNA clone. J Virol 80(7):3670-3674. https://doi.org/10. 1128/JVI.80.7.3670-3674.2006

11. Li J, Jin Z, Gao Y, Zhou L, Ge X, Guo X, Han J, Yang H (2017) Development of the full-length cDNA clones of two porcine epidemic diarrhea disease virus isolates with different virulence. PLoS One 12(3):e0173998. https://doi.org/10.1371/journal.pone. 0173998

12. Zeng LP, Gao YT, Ge XY, Zhang Q, Peng C, Yang XL, Tan B, Chen J, Chmura AA, Daszak P, Shi ZL (2016) Bat severe acute respiratory syndrome-like coronavirus WIVI encodes an extra accessory protein, ORFX, involved in modulation of the host immune response. J Virol 90(14):6573-6582. https:// doi.org/10.1128/JVI.03079-15

13. Murphy KC (1998) Use of bacteriophage lambda recombination functions to promote gene replacement in Escherichia coli. J Bacteriol 180(8):2063-2071

14. Oppenheim AB, Rattray AJ, Bubunenko M, Thomason LC, Court DL (2004) In vivo recombineering of bacteriophage lambda by PCR fragments and single-strand oligonucleotides. Virology 319(2):185-189. https://doi. org/10.1016/j.virol.2003.11.007

15. Lee EC, Yu D, Martinez de Velasco J, Tessarollo L, Swing DA, Court DL, Jenkins NA, Copeland NG (2001) A highly efficient Escherichia coli-based chromosome engineering system adapted for recombinogenic targeting and subcloning of BAC DNA. Genomics 73(1):56-65. https://doi.org/10.1006/ geno.2000.6451

16. Zhang Y, Buchholz F, Muyrers JP, Stewart AF (1998) A new logic for DNA engineering using recombination in Escherichia coli. Nat Genet 20(2):123-128. https://doi.org/10.1038/ 2417

17. Warming S, Costantino N, Court DL, Jenkins NA, Copeland NG (2005) Simple and highly efficient BAC recombineering using galK selection. Nucleic Acids Res 33(4):e36. https://doi. org/10.1093/nar/gni035

18. Tischer BK, von Einem J, Kaufer B, Osterrieder N (2006) Two-step red-mediated recombination for versatile high-efficiency markerless DNA manipulation in Escherichia coli. BioTechniques 40(2):191-197

19. Almazan F, Marquez-Jurado S, Nogales A, Enjuanes L (2015) Engineering infectious cDNAs of coronavirus as bacterial artificial chromosomes. Methods Mol Biol 1282:135-152. https://doi.org/10.1007/ 978-1-4939-2438-7_13

20. Tischer BK, Smith GA, Osterrieder N (2010) En passant mutagenesis: a two step markerless red recombination system. Methods Mol Biol 634:421-430. https://doi.org/10.1007/ 978-1-60761-652-8_30 